\title{
Labor Rights as Human Rights? Challenges and Prospects for Collective Bargaining
}

\author{
George Andreopoulos
}

Published online: 31 July 2012

(C) Springer Science+Business Media B.V. 2012

The recent controversy surrounding attempts by several state governors and legislatures in the USA to strip public workers of their collective bargaining rights has rekindled debates on the status of such rights in the country and ensured that battle lines would be drawn over this issue in the upcoming elections. Human Rights Review has decided to launch its Current Issues and Controversies section with an agora on this critical public policy issue area, since it raises important questions about the status and future prospects of labor rights in the electoral arena and beyond and the strengths and limitations of the human rights discourse as a tool in the effort to respond effectively to the attacks against collective bargaining and public sector unions.

The latest chapter in this saga was the unsuccessful effort to recall Wisconsin Governor Scott Walker following his signing into law, a few weeks after coming into office last year, a bill stripping public employees of most collective bargaining rights. ${ }^{1}$ Governor Walker's argument in supporting this law was that these limits on public employee bargaining rights, as well as the requirement that public employees pay more for their health care benefits and pensions, were necessary to help close a potential \$3.6 shortfall in the state's 2-year budget cycle (2011-2013). ${ }^{2}$ Critics countered that unions were not responsible for the projected deficit, and stripping workers of their collective bargaining rights would not save any money. According to them, a key contributing factor to the problem with the budget was the adoption of a

\footnotetext{
${ }^{1}$ For the text of the Budget Repair Bill, see http://legis.wisconsin.gov/insession/insessiondocs/docs/JR1AB11CA1.pdf. It is important to note that most public safety employees at the city and county level (this would include firefighters, police officers, state troopers, and sheriff deputies) were exempted from the bargaining restrictions.

${ }^{2}$ Douglas Belkin, Colleen McCain Nelson, and Caroline Porter, "Walker Prevails in Recall Vote," The Wall Street Journal, June 6, 2012.
}

G. Andreopoulos $(\bowtie)$

The Department of Political Science, John Jay College of Criminal Justice and the Graduate Center, City University of New York, 445 West 59th Street, Room 3231 North Hall, New York, NY 10019, USA e-mail: gandreopoulos@jjay.cuny.edu 
series of tax breaks, approved by the legislature shortly after Walker's inauguration, which led to a dramatic increase in the budget deficit. ${ }^{3}$ The targeting of public sector unions and the simultaneous exemption of public safety employees from the bargaining restrictions were indicative, critics argued, of "pure partisan warfare": an attempt "to defund the unions that form the backbone of the Democratic party." 4 In a similar vein, the New York Times argued, in its editorial on the immediate aftermath of the recall vote, that Governor Walker's "real goal was political: to break the unions by demonizing their "bosses," ending their ability even to collect dues and removing them as a source of money and energy for Democrats." 5

Wisconsin is one of several battlefield states in which labor rights have been challenged within the context of an ongoing or looming fiscal crisis. Public sector unionism has faced varying challenges in, among other places, Ohio, North Carolina, Florida, Michigan, and New Jersey, and there is no indication that these challenges will abate anytime soon. On the contrary, as Joe McCartin notes in his contribution, "the fight for the future of public sector unionism is settling down into grinding stateby-state trench warfare that is likely to extend indefinitely into the future." According to him, not only are the organizational resources of unions put to the test here, but also their arguments.

This "expanding battlefield" constitutes a fertile ground on which to test competing arguments and contending approaches to labor rights issues. One of the key issues here is the relevance of the human rights discourse and the corresponding international legal instruments in the defense of labor rights. To be sure, the human rights and labor rights movements have several things in common (in particular, a shared commitment to justice and an advocacy on behalf of the oppressed); ${ }^{6}$ yet, traditionally, the human rights movement has paid little attention to workers' rights and, in defending their cause, trade unions have likewise rarely enlisted the support of human rights groups. As one analyst has aptly noted, the two movements, human rights and labor, have long run on sometimes parallel and rarely intersecting tracks. $^{7}$

In recent years, however, there has been a noticeable change to this trend as labor organizations and scholars have increasingly turned their attention to the way in which international norms regarding labor rights, in particular on issues pertaining to freedom of association and collective bargaining, could contribute to the reform of domestic labor law. ${ }^{8}$ In a statement sent to Wisconsin legislators, the International Commission for Labor Rights, after briefly surveying the relevant international legal

\footnotetext{
$\overline{3}$ Andy Kroll with Nick Baumann and Siddhartha Mahanta, "What's Happening in Wisconsin Explained," Mother Jones, March 17, 2011; http://www.motherjones.com/mojo/2011/02/whats-happening-wisconsinexplained

4 Ibid, and Kevin Drum, "Defunding the Democratic Party," February 17, 2011; http://www.motherjones.com/ kevin-drum/2011/02/defunding-democratic-party

5 “The Message From Wisconsin,” The New York Times, June 6, 2012, http://www.nytimes.com/2012/06/ 07/opinion/the-message-from-wisconsins-recall-election.html

${ }^{6}$ Kevin Kolben, “Labor Rights as Human Rights?" Virginia Journal of International Law, vol. 50 (2), 2010 , p. 450.

${ }^{7}$ Virginia A. Leary, "The Paradox of Workers' Rights as Human Rights," in Lance Compa and Stephen Diamond (eds.), Human Rights, Labor Rights and International Trade, University of Pennsylvania Press, 1996, p. 22; see also Kolben, ibid.

${ }^{8}$ Kolben, ibid, p. 451.
} 
instruments, domestic and foreign court cases, and rulings by the International Labour Organization's (ILO) Committee on Freedom of Association, concluded that "the right of public sector workers to form trade unions and to bargain collectively are fundamental rights which have attained a global consensus also known as customary international law and are binding on all states of the United States and to deny or restrict them would be illegal." 9

In this vein, two of our contributors Lance Compa and Susan Kang argue that collective bargaining is a human right, not a privilege. Compa highlights the relevance of the international human rights and labor rights framework and notes that the ILO has consistently "applied international freedom of association standards to public employees." In advancing his argument, he examines the relevant case law before international, regional, and foreign fora and notes that most major advanced democracies do honor public employees' collective bargaining rights. ${ }^{10}$ The USA's hybrid status and the recent labor rights crisis pose challenges that a heightened awareness of international labor standards will have to address. Kang focuses on the recent fights over collective bargaining rights in Ohio and Wisconsin. She addresses the two key arguments raised by proponents of limiting such rights, namely the instrumental (fiscal crisis) and the normative (collective bargaining as a privilege, not a right) and finds them wanting. Concerning the latter, she argues that though Wisconsin Governor Walker sought to frame such limitations in rights language (as necessary to protect workers' individual right to choose and right to information), the ILO has "rejected this dichotomy between individual and collective rights." While she acknowledges the contested nature of international human rights standards in the USA, there is evidence that such standards maintain a significant degree of legitimacy among many communities in the country.

However, there is an alternative tradition in rights discourse that would be supportive of Governor Walker's framing and would advance a different understanding of the meaning of the freedom of association. Joe McCartin notes that the history of anti-unionism in the USA has its own "well-developed language of rights... one quite capable of deflecting appeals to human rights with a sturdy assertion of individual rights." Charles Baird's contribution seeks to advance such an assertion. According to him, freedom of association is a non-rivalrous right, which requires mutual consent. In order to make sense, freedom of association "must include the right to accept and the right to reject association." One of the main problems with public sector collective bargaining is that it imposes exclusive representation on employers and employees, an imposition which constitutes "a violation of the entitlement condition for voluntary exchange." In response to the argument that exclusive representation would be necessary to protect unions from free riders, Baird notes that, although some free riding could conceivably occur, this problem "could be almost eliminated simply by repealing exclusive representation." What Governor Walker and the Wisconsin

\footnotetext{
${ }^{9}$ International Commission for Labor Rights, Collective Bargaining Rights Are Fundamental Human Rights-Denying Them Is Illegal, March 2, 2011; http://www.laborcommission.org/ICLR-statement-rightof-public-employees-to-bargain-collectively.pdf

${ }^{10}$ These are the countries that the USA considers as its natural allies on international human rights issues; yet on several of these issues, the USA is often an outlier. Such status is not confined to economic, social, and cultural rights issues (the "usual suspects"), as is demonstrated by the USA's position on the death penalty.
} 
legislature did, Baird concludes, is challenge "arbitrary privileges pretending to be human rights."

This debate raises another critical question: if there are some limitations in human rights argumentation, what other venues are available to the labor movement and to all those eager to ensure the defense of collective bargaining? Joe McCartin argues that labor needs to broaden its defense of collective bargaining beyond human rights arguments. Although he is sympathetic to many of these arguments, he believes that American anti-unionism, by framing its attack on collective bargaining as a defense of workers' rights, "has largely inoculated itself against appeals to human rights and to the right to free association." According to him, the whole discussion needs to be placed within the larger context of a systemic problem emerging from the transformation of the economic environment, the weakening of the regulatory capacities of the state, and the eroding capacity of workers to stage successful collective actions. What is urgently needed, McCartin notes, is the articulation of a new vision around which the labor movement can rally today, a vision analogous to the idea of industrial democracy advanced in an earlier era by labor activists. Such a vision would transcend organized labor's image as that of a mere rights-seeking group. Instead, it would cast labor as "the agent of a broader social movement"; a movement "essential to democracy, the common good, and social, economic, and environmental sustainability."

As the contributions that follow indicate, collective bargaining is and will continue to be a highly contentious issue. At stake is the extent to which the human rights discourse is a necessary resource in the effort to address the challenges confronting it, as well as the current status and future prospects of labor rights. We trust that this agora will make a contribution to this important and ongoing conversation. 